\title{
Aplikasi Machine Vision pada Hexacopter untuk Deteksi Survival Kits di Bidang Mitigasi Bencana
}

\author{
Ismawan Noor Ikhsan ${ }^{1}$ dan Son Ali Akbar ${ }^{2}$ \\ Jurusan Teknik Elektro, Fakultas Teknologi Industri, Universitas Ahmad Dahlan \\ Kampus IV UAD, Jl. Ringroad Selatan, Tamanan, Banguntapan, Yogyakarta, 55166, Indonesia \\ ismawan1615022074@webmail.uad.ac.id ${ }^{1}$,sonali@ee.uad.ac.id ${ }^{2}$
}

\begin{abstract}
Hexacopter bel ongs to one of flying robots that is used to carry out a special mission such as retrieving and delivering survival kits object. Thus, it should be built by smart system to determine the object accurately. However, there was an interference from other object that made it difficult to recognize the survival kits object. Therefore, the development of machine vision with the integration of the hexacopter control system is expected to improve the object recognition process. This study intends to devel op a survival kit detection using the image processing method, which invol ved 1) segmentation on the Hue, Saturation, Value (HSV) color space, 2) contour detection, and 3) Region of Interest (ROI) selected detection. The evaluation of the segmentation method performances was done through the three-part experiments (i.e., the similar shape, variety of a color object, and an object shape). The result of survival kits object detection evaluation obtained an accuracy of $90.33 \%$, precision of $99.63 \%$, and recall of 91.24\%. According to the performances obtained in this study, the devel opment of machine vision systems on Unmanned Aerial Vehicle (UAV) has a high accuracy for the object survival kits detection even with another object interference.
\end{abstract}

Keywords- hexacopter, machine vision, HSV, contour, ROI

Abstrak- Hexacopter merupakan salah satu robot terbang yang digunakan untuk melalukan misi khusus. Salah satu contohnya, misi mengambil dan mengirimkan objek survival kits. Hexacopter perlu dikembangkan dengan sistem cerdas untuk menentukan objek secara aku rat. Permasalahan yang ditemukan adalah gangguan objek lain sehingga kesulitan dalam mengenali objek survival kits. Pengembangan machine vision dengan integrasi sistem kendali hexacopter diharapkan mampu meningkatkan proses pengenalan objek. Pada penelitian ini, dikembangkan sistem deteksi objek survival kits yang terdiri dari tiga proses utama yaitu 1) segmentasi pada ruang warna Hue, Saturation, Val ue (HSV), 2) deteksi kontur, dan 3) deteksi Region of Interest (ROI). Evaluasi kinerja metode segmentasi dilakukan melalui tiga pengujian, yaitu gangguan objek dimensi sama, gangguan objek warna lain, dan gangguan objek bentuk lain. Hasil evaluasi kinerja deteksi objek survival kits adalah akurasi sebesar 90,33\%, presisi sebesar 99,63\%, dan recall sebesar $\mathbf{9 1 , 2 4 \%}$. Berdasarkan kinerja yang diperoleh dalam penelitian ini, pengembangan sistem machine vision pada Unmanned Aerial Vehicle (UAV) memiliki ketepatan tinggi untuk deteksi objek survival kits meskipun diberikan gangguan objek lain.

Kata kunci-hexacopter, machine vision, HS V, kontur, ROI

\section{PENDAHULUAN}

Unmanned Aerial Vehicle (UAV) merupakan robot terbang tanpa awak yang digunakan dalam suatu misi penerbangan [1]. UAV dikelompokkan menjadi dua jenis yaitu fixed wing jenis pesawat dan rotary wing jenis multicopter. Multicopter dikenal sebagai wahana Vertikal Take Off and Landing (VTOL) karena UA V dapat melakukan take off dan landing secara vertikal tanpa memerlukan landasan yang luas [2]. Salah satu jenis VTOL UAV adalah hexacopter. Hexacopter dengan 6 buah motor penggerak memiliki karakteristik kemampuan manuver yang baik dan stabilitas tinggi [3]. Penggunaan UAV berjen is multicopter pada bidang pemetaan, pemantauan udara, dan penangangan bencana alam memiliki kestabilan yang baik dibandingkan UAV jenis pesawat [4] - [6].
Pemanfaatan UAV dalam pengambilan dan pengiriman barang berupa objek survival kits ke suatu lokasi merupakan salah satu misi yang dilaku kan dalam mitigasi bencana [7], [8]. Dalam misi yang dilakukan diperlukan sistem pengenalan lokasi dan jen is objek Muatan Pick (MP) survival kits. MP survival kits merupakan objek yang digunakan dalam penelitian berupa survival kits dengan bentuk khusus berwarna oranye sebagai barang logistik untuk diambil dan diangkut pada UAV. Pengenalan lokasi dan objek dengan menggunakan Global Positioning System (GPS) tidak disarankan karena sifat GPS yang tidak dapat mengenali jenis objek [9]. Permasalahan yang ditemukan adalah gangguan objek lain terdeteksi selain objek MP survival kits di sekitar lokasi survival kits. Penerapan machine vision merupakan salah satu pilihan untuk diimplementasikan pada hexacopter agar hexacopter dapat mengenali objek survival kits pada lokasi survival kits. Penggunaan sensor kamera yang 
terpasang pada UAV sebagai perangkat machine vision dapat digunakan dalam proses deteksi sebuah objek [10].

Pengolahan citra merupakan bagian penting dari machine vision yang umum digunakan dalam UA V. Pengolahan citra diaplikasikan pada berbagai robot dan sistem oto masi berbasis pengenalan objek, salah satunya adalah teknik segmentasi warna. Beberapa penelitian te lah dilakukan, proses segmentasi pada ruang warna Hue, Saturation, Value (HSV) digunakan dalam pendeteksian objek berdasarkan analisis warna [11] [14]. Penelitian [11] melakukan deteksi objek menggunakan segmentasi objek pada ruang warna HSV menunjukkan bahwa warna HSV berfungsi sebagai nilai acuan untuk memisahkan objek dari background citra. Segmentasi pada ruang warna HSV memiliki hasil yang lebih baik dibandingkan ruang warna CIELAB. Kelemahan dari metode HSV adalah gangguan noise dalam deteksi objek akibat kemiripan warna objek lain sehingga mengakibatkan proses deteksi objek menjadi tidak sempurna [15], [16]. Perbandingan segmentasi HSV dengan segmentasi warna lainnya yaitu segmentasi Red, Green, Blue (RGB) yang dilakukan oleh [12] dan [13] diperoleh kesimpulan bahwa penggunaan segmentasi HSV masih memiliki performa akurasi deteksi yang lebih tinggi. Keunggulan segmentasi objek pada ruang warna memiliki ketahanan terhadap perubahan intensitas dibandingkan metode lain sehingga cocok digunakan untuk deteksi objek [17].

Penerapan proses deteksi Region of Interest (ROI) digunakan untuk me mbatasi area deteksi objek sehingga dapat meminimalisir noise dalam proses segmentasi objek [18] [20]. Penelitian mengenai pendeteksian objek berdasarkan analisis bentuk telah dilakukan menggunakan metode deteksi kontur [21] - [23]. Pada penelitian [21] dijelaskan bahwa menemukan kontur merupakan salah satu bagian penting dari pelacakan objek. Deteksi kontur menjadi salah satu metode yang efisien dalam mendeteksi beberapa objek secara bersamaan. Kontur dapat digunakan dalam analisis bentuk, menentukan ukuran sebuah objek, dan deteksi objek. Fiturfitur deteksi kontur diantaranya: moments, contour area, contour perimeter, contour approximation, dan convex hull. Penggabungan analisis warna dan bentuk diharapkan dapat meningkatkan keberhasilan dan ketepatan dalam pendeteksian objek.

Tujuan penelitian ini adalah mengembangkan sistem machine vision pada hexacopter untuk pendeteksian objek MP survival kits. Pengembangan machine vision pada hexacopter diharapkan menjadi solusi dalam permasalahan yang ditemukan sehingga hexacopter dapat mengenali objek MP survival kits. Metode yang diusulkan dalam penelitian ini menggunakan metode segmentasi warna HSV, deteksi kontur, dan deteksi ROI. Metode segmentasi warna HSV dan deteksi kontur digunakan untuk pengenalan objek MP survival kits berdasarkan ciri warna dan bentuk. Deteksi ROI untuk membatasi area pendeteksian objek survival kits sehingga dapat mengurangi noise dan lebih meningkatkan akurasi pendeteksian objek MP survival kits. Metode yang dikembangkan diharapkan mendukung pendeteksian objek MP survival kits pada hexacopter.

\section{METODE}

Deteksi objek MP survival kits pada hexacopter untuk suatu penyelesaian misi yang dilakukan menggunakan penerapan machine vision. Bahasa pemrograman Python dan library OpenCV digunakan dalam pengolahan citra pada penelitian ini. Metode yang diusulkan dalam deteksi objek MP survival kits terbagi menjadi 2 tahapan proses yaitu pengenalan lokasi survival kits dan pengenalan objek MP survival kits. Diagram blok proses pendeteksian objek survival kits pada hexacopter dengan machine vision dijelaskan pada Gambar 1.

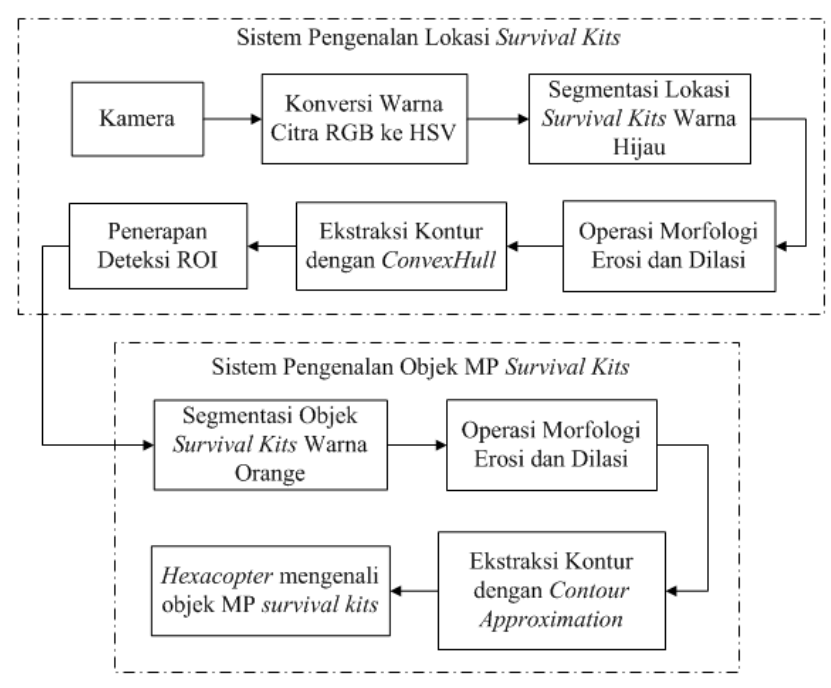

Gambar 1. Diagram blok proses deteksi objek

\section{A. Proses Pengenalan Lokasi Survival Kits}

Tahap awal yang dilakukan adalah proses menangkap citra lokasi dan objek survival kits menggunakan kamera. Kamera memberikan input pada sistem berupa citra berbentuk video capture secara real-time. Ukuran frame video real-time yang digunakan adalah 640x480 piksel. Untuk mengurangi efek iluminasi pada citra, maka dilakukan konversi ke ruang warna HSV.

Tahap kedua, citra RGB dari frame video real-time dikonversikan ke bentuk citra HSV. Dalam proses konversi RGB ke HSV diperlukan informasi nilai minimum dan maksimum dari nilai RGB. Nilai RGB dapat diperoleh menggunakan (1).

$$
\begin{gathered}
C \max =\max (R, G, B) \\
C \min =\min (R, G, B) \\
C=C \max -C \min
\end{gathered}
$$

Setelah diperoleh nilai minimum dan maksimum untuk warna RGB, maka nilai HSV didapatkan menggunakan (2) (4).

$$
H=\left\{\begin{array}{l}
60^{\circ} \times\left(\frac{G-B}{\Delta}\right), C \max =R \\
60^{\circ} \times\left(\frac{B-R}{\Delta}+2\right), C \max =G \\
60^{\circ} \times\left(\frac{R-G}{\Delta}+4\right), C \max =B
\end{array}\right.
$$


Juli - Desember 2020

$$
\begin{gathered}
S=\left\{\begin{array}{c}
0, C \max =0 \\
\frac{\Delta}{C \max }, C \max \neq 0
\end{array}\right. \\
V=C \max
\end{gathered}
$$

Setelah citra HSV diperoleh, citra akan dilakukan proses segmentasi lokasi survival kits yang berwarna hijau untuk didapatkan thresholding citra. Proses thresholding bertujuan untuk memisahkan antara foreground dan background citra lokasi survival kits, dimana nilai piksel foreground akan bernilai 1 dan nilai piksel background bernilai 0 . Berdasarkan hasil eksperimen yang dilakukan pada segmentasi lokasi survival kits, maka nilai minimum dan maksimum yang optimal dari ruang warna HSV adalah hsv_min $(75,0,100)$ dan hsv_max $(179,255,255)$.

Tahapan selanjutnya adalah operasi morfologi berupa erosi dan dilasi. Operasi morfologi diterapkan untuk meminimalisir noise pada hasil segmentasi lokasi survival kits. Proses erosi digunakan mengikis sebagian objek berupa noise dari hasil deteksi objek dengan cara mengurangi piksel area foreground yang dijelaskan pada (5). Di mana, $E$ merupakan himpunan hasil dilasi, $A$ adalah himpunan citra asal, dan $S$ merupakan himpunan dari structuring element. Pada proses erosi hasil segmentasi lokasi survival kits menggunakan struktur elemen matrik berukuran $3 \times 3$ dengan iterasi $=1$.

$$
E(A, S)=A \ominus S
$$

Proses dilasi terhadap citra hasil segmentasi lokasi survival kits bertujuan mempertajam atau mempertebal hasil deteksi dengan menambahkan piksel pada area foreground yang dije laskan pada (6). Di mana, $D$ merupakan himpunan hasil dilasi, $A$ adalah himpunan citra asal, dan $S$ merupakan himpunan dari structuring element. Pada proses dilasi hasil segmentasi lokasi survival kits menggunakan struktur elemen matrik berukuran $10 \times 10$ dengan iterasi $=1$.

$$
D(A, S)=A \oplus S
$$

Tahap selanjutnya dilakukan ekstraksi kontur. Pencarian kontur dilakukan menggunakan fungsi FindContour pada OpenCV Python dengan mode CV_RETR_TREE dan metode CV_CHAIN_APPROX_SIMPLE. Mode CV_RETR_TREE berfungsi mengambil semua kontur dan merekonstruksi seluruh hierarki kontur. Metode CV_CHAIN_APPROX_SIMPLE berfungsi menghapus semua titik redundan dan memampatkan kontur. Pencarian kontur dilakukan untuk mendapatkan area kontur terbesar. Selanjutnya, luas area kontur lokasi survival kits yang terdeteksi akan digambar menggunakan fungsi convex hull pada OpenCV Python. Dalam hal ini fungsi convex hull direpresentasikan sebagai penyatuan kontur dengan menyambungkan titik kontur terluar menggunakan garis dari kontur yang didapat sebelumnya. Hasil ekstraksi kontur lokasi survival kits akan diberi bounding rect sebagai penanda area lokasi survival kits.

Setelah hasil pengenalan lokasi survival kits diperoleh, dilakukan proses deteksi ROI. Deteksi ROI dilakukan dengan pembatasan area frame citra berdasarkan koordinat hasil ekstraksi kontur lokasi survival kits. Penggunaan deteksi ROI bertujuan untuk pembatasan area deteksi objek MP survival kits sehingga diharapkan hanya objek MP survival kits di dalam area lokasi survival kits yang akan dideteksi.

\section{B. Proses Pengenalan Objek MP Survival Kits}

Tahap awal yang dilakukan dalam deteksi objek MP survival kits yaitu mengambil frame gambar melalui proses ROI pada citra hasil pengenalan lokasi survival kits. Tahap kedua, citra RGB dari proses deteksi ROI dikonversikan ke bentuk citra HSV. Dalam proses konversi RGB ke HSV diperlukan informasi nilai minimum dan maksimum dari nilai RGB. Nilai RGB dapat diperoleh menggunakan (1). Setelah diperoleh nilai minimum dan maksimum untuk warna RGB, maka nilai HSV didapatkan menggunakan (2) - (4).

Setelah citra HSV diperoleh, citra akan dilakukan proses segmentasi objek MP survival kits yang berwarna oranye untuk didapatkan thresholding citra. Proses thresholding bertujuan untuk memisahkan antara foreground dan background citra objek MP survival kits, dimana nilai piksel foreground akan bernilai 1 dan nilai piksel background bernilai 0 . Berdasarkan hasil eksperimen yang dilakukan pada segmentasi objek MP survival kits, maka nilai minimum dan maksimum yang optimal dari ruang warna HSV adalah hsv_min $(10,105,210)$ dan hsv_max $(60,255,255)$.

Tahapan selanjutnya adalah operasi morfologi berupa erosi dan dilasi pada hasil segmentasi objek MP survival kits. Operasi morfologi diterapkan untuk meminimalisir noise pada hasil segmentasi objek MP survival kits. Tahapan operasi morfologi berupa erosi dan dilasi serta ekstraksi kontur pada objek MP survival kits menggunakan proses yang sama seperti pada deteksi lokasi survival kits. Area kontur segmentasi objek MP survival kits yang didapatkan akan dilakukan perhitungan titik-titik penyusun kontur yang terbentuk menggunakan fungsi cv2.approxPolyDP. Selanjutnya titiktitik kontur yang terbentuk akan diperkirakan ke dalam ciri bentuk berdasarkan titik aproksimasi kontur menggunakan contour approximation. Klasifikasi objek dengan menganalis a titik-titik penyusun aproksimasi kontur jika lebih dari 8 titik maka kontur akan ditandai pointer lingkaran dan komentar "MP". Hasil ekstraksi kontur tersebut selanjutnya akan dikenali sebagai objek MP survival kits.

Perangkat sistem machine vision yang digunakan pada hexacopter dijelaskan pada Gambar 2. Pengunaan kamera Xiaomi Yi terpasang pada hexacopter berfungsi sebagai perangkat untuk mengenali objek survival kits di lokasi survival kits. Perangkat transmitter FPV TS5828 akan mengirimkan data video ke receiver FPV RC832 pada ground station sehingga terjadi proses komunikasi pengiriman data video dari hexacopter ke ground station. Data video yang telah diterima akan diproses pada laptop untuk didapatkan hasil pengenalan objek survival kits. Perangkat laptop digunakan pemroses utama machine vision di ground station.

Pada sistem machine vision yang dikembangkan, diharapkan hexacopter mampu mengenali objek survival kits yang berada di lokasi survival kits. Hexacopter akan mengenali lokasi survival kits berupa objek berbentuk persegi warna hijau, kemudian mendeteksi objek MP survival kits berwarna oranye seperti diilustrasikan pada Gambar 3. MP survival kits merupakan salah satu jenis dari objek survival 
kits yang digunakan dalam penelitian ini. Lokasi survival kits diilustrasikan objek persegi berwarna hijau dengan ukuran $2 \times 2 \mathrm{~m}^{2}$. Objek MP survival kits memiliki dimensi ukuran dengan diameter $20 \mathrm{~cm}$ dan tinggi $20 \mathrm{~cm}$ berwarna oranye.

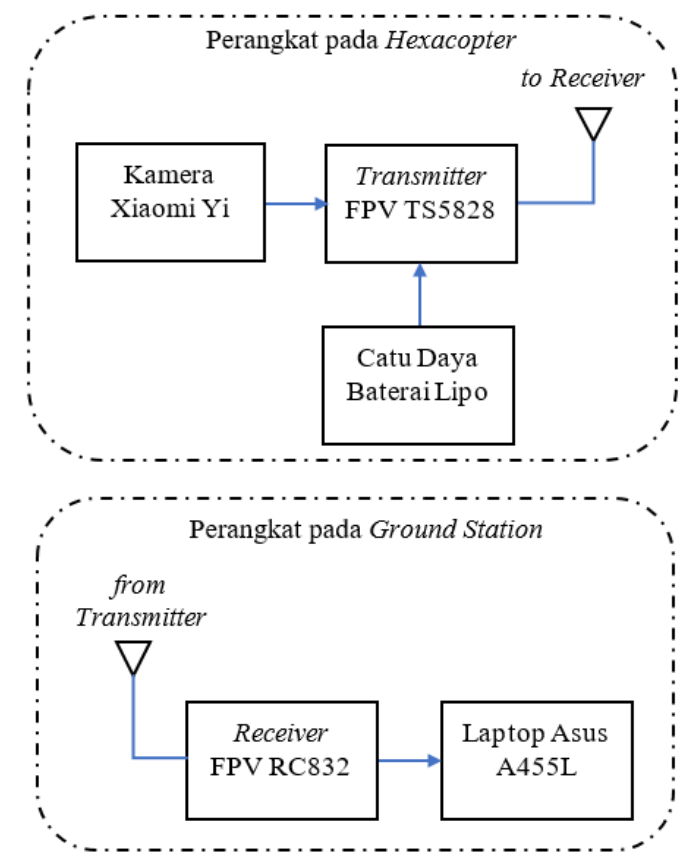

Gambar 2. Perangkat machine vision pada hexacopter

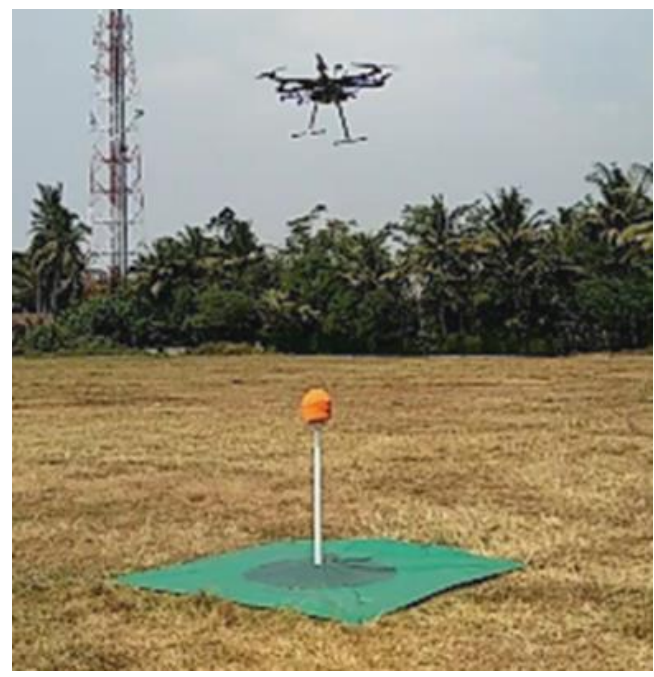

Gambar 3. Proses deteksi objek pada hexacopter

\section{HASIL DAN PEMBAHASAN}

Evaluasi segmentasi objek dilakukan dengan memberikan gangguan berupa objek lain, diharapkan sistem yang dikembangkan hanya mendeteksi objek MP survival kits dan mengabaikan gangguan objek lain. Evaluasi ini dibagi menjadi tiga bagian, yaitu: evaluasi segmentasi objek dengan gangguan objek dimensi sama, bentuk lain, dan warna lain. Pada evaluasi ini, hasil pendeteksian objek survival kits diklasifikasi dalam True Positive (TP), False Positive (FP), True Negative (TN), dan False Negative (FN) untuk didapatkan evaluasi segmentasi objek berupa akurasi, presisi, dan recall [18]. TP dimana sistem mendeteksi objek survival kits dengan benar. FP dimana sistem mendeteksi objek gangguan atau objek lainnya sebagai objek survival kits. FN dimana sistem tidak mendeteksi objek survival kits. TN dimana sistem tidak mendeteksi objek dalam frame. Hasil akurasi, presisi, dan recall diperoleh menggunakan (7) - (9).

$$
\begin{gathered}
\text { Akurasi }=\frac{T P+T N}{T P+T N+F P+F N} \times 100 \% \\
\text { Presisi }=\frac{T P}{T P+F P} \times 100 \% \\
\text { Recall }=\frac{T P}{T P+F N} \times 100 \%
\end{gathered}
$$

Dalam evaluasi segmentasi objek survival kits menggunakan parameter warna HSV dimana untuk segmentasi objek berupa lokasi survival kits berwarna hijau dan objek MP survival kits berwarna oranye. Parameter warna HSV ditunjukkan pada Tabel I.

TABEL I. PARAMETER WARNA HSV

\begin{tabular}{|c|c|c|c|c|c|c|}
\hline \multirow{2}{*}{ Warna } & \multicolumn{2}{|c|}{ Nilai Hue } & \multicolumn{2}{c|}{ Nilai Saturation } & \multicolumn{2}{c|}{ Nilai Value } \\
\cline { 2 - 7 } & Min & Max & Min & Max & Min & Max \\
\hline Hijau & 75 & 179 & 0 & 255 & 100 & 255 \\
\hline Oranye & 10 & 60 & 105 & 255 & 210 & 255 \\
\hline
\end{tabular}

A. Evaluasi Segmentasi Objek Survival Kits dengan Gangguan Objek Dimensi Sama

Evaluasi segmentasi objek survival kits dilakukan dengan diberikan gangguan objek dimensi sama berwarna oranye dengan ukuran diameter $20 \mathrm{~cm}$ dan tinggi $20 \mathrm{~cm}$ sesuai dimensi objek survival kits. Aplikasi Graphic User Interface (GUI) yang digunakan pada penelitian ini ditunjukkan pada Gambar 4. GUI menampilkan nilai parameter warna HSV, hasil segmentasi lokasi MP survival kits, hasil segmentasi objek MP survival kits, hasil ROI image, dan hasil pengenalan objek MP survival kits.

Pengambilan data menggunakan hexacopter yang diterbangkan ke lokasi survival kits dengan ketinggian $3 \mathrm{~m}$. Pengambilan data yang dilakukan dengan mengambil data sebanyak 20 frame citra dari video real-time berdurasi 1 menit pada setiap uji evaluasi. Evaluasi segmentasi objek survival kits dengan gangguan objek dimensi sama dilakukan sebanyak 15 kali uji. Hasil evaluasi segmentasi dengan gangguan objek dimensi sama ditunjukkan pada Tabel II.

Mengacu pada Tabel II, evaluasi segmentasi objek survival kits dengan gangguan objek dimensi sama diperoleh rata-rata hasil akurasi sebesar $89,75 \%$, p resisi sebes ar $98,30 \%$, dan recall sebesar 91,24\%. Sistem yang dikembangkan pada UAV dapat mengenali dan tracking objek MP survival kits yang berada dalam area lokasi survival kits serta mampu mengabaikan gangguan objek dimensi sama di sekitar lokasi survival kits.

Sistem mampu mengklasifikasikan hasil segmentasi sebagai objek survival kits walaupun diberikan gangguan objek dimensi sama sehingga diperoleh hasil akurasi yang tinggi sebesar $89,75 \%$. Akurasi rendah didapatkan pada evaluasi segmentasi uji ke-8 dan uji ke-11. Dalam evaluasi segmentasi uji ke-8 menunjukkan sistem belum mampu melakukan segmentasi dengan baik diakibatkan kesalahan sistem yang tidak dapat mendeteksi objek survival kits. Dalam 
evaluasi segmentasi uji ke-11 menunjukkan sistem belum mampu melakukan segmentasi dengan baik diakibatkan kesalahan sistem dalam mendeteksi objek lain sebagai objek survival kits. Faktor lain yang menyebabkan kesalahan deteksi objek survival kits diantaranya kamera tidak dapat menangkap objek survival kits dengan baik akibat gangguan komunikasi perangkat FPV pada saat pengiriman video real-time.

B. Evaluasi Segmentasi Objek Survival Kits dengan Gangguan Objek Warna Lain

Evaluasi segmentasi objek survival kits dilakukan dengan diberikan gangguan objek berwarna putih dengan ukuran diameter $20 \mathrm{~cm}$ dan tinggi $20 \mathrm{~cm}$. Aplikasi GUI menampilkan nilai parameter warna HSV, hasil segmentasi lokasi MP survival kits, hasil segmentasi objek MP survival kits, hasil ROI image, dan hasil pengenalan objek MP survival kits ditunjukkan pada Gambar 5.

Pengambilan data menggunakan hexacopter yang diterbangkan ke lokasi survival kits dengan ketinggian $3 \mathrm{~m}$. Pengambilan data yang dilakukan dengan mengambil data sebanyak 20 frame citra dari video real-time berdurasi 1 menit pada setiap uji evaluasi. Evaluasi segmentasi objek survival kits dengan gangguan objek warna lain dilakukan sebanyak 15 kali uji. Hasil evaluasi segmentasi dengan gangguan objek warna lain ditunjukkan pada Tabel III.

Mengacu pada Tabel III, evaluasi segmentasi objek survival kits dengan gangguan objek warna lain diperoleh rata-rata hasil akurasi sebesar 90,33\%, presisi sebesar 99,63\%, dan recall sebesar $90,63 \%$. Sistem yang dikembangkan pada UAV dapat mengenali dan tracking objek MP survival kits yang berada dalam area lokasi survival kits serta mampu mengabaikan gangguan objek warna lain di sekitar lokasi survival kits.

Sistem mampu mengklasifikasikan hasil segmentasi sebagai objek survival kits walaupun diberikan gangguan objek warna lain sehingga diperoleh hasil aku rasi yang tinggi sebesar 90,33\%. Akurasi rendah didapatkan pada evaluasi segmentasi uji ke-3. Dalam evaluasi segmentasi uji ke-3 menunjukkan sistem belum mampu melakukan segmentasi dengan baik diakibatkan kesalahan sistem yang tidak dapat mendeteksi objek survival kits. Faktor lain yang menyebabkan kesalahan deteksi objek survival kits diantaranya kamera tidak dapat menangkap objek survival kits dengan baik akibat gangguan komunikasi perangkat FPV pada saat pengiriman video real-time.

TABEL II. Hasil EVAluasi SEgmENTASI DENGAN GANGGUAN ObJeK DIMENSI SAMA

\begin{tabular}{|c|c|c|c|c|c|c|c|}
\hline Uji & TP & FP & FN & $\mathbf{T N}$ & $\begin{array}{c}\text { Accuracy } \\
(\%)\end{array}$ & $\begin{array}{c}\text { Precision } \\
(\%)\end{array}$ & $\begin{array}{c}\text { Recall } \\
(\%)\end{array}$ \\
\hline 1 & 19 & 0 & 1 & 0 & 95 & 100 & 95 \\
\hline 2 & 19 & 0 & 0 & 0 & 100 & 100 & 100 \\
\hline 3 & 18 & 0 & 2 & 0 & 90 & 100 & 90 \\
\hline 4 & 17 & 0 & 3 & 0 & 85 & 100 & 85 \\
\hline 5 & 17 & 0 & 3 & 0 & 85 & 100 & 85 \\
\hline 6 & 19 & 0 & 1 & 0 & 95 & 100 & 95 \\
\hline 7 & 17 & 0 & 3 & 0 & 85 & 100 & 85 \\
\hline 8 & 14 & 0 & 6 & 0 & 70 & 100 & 70 \\
\hline 9 & 18 & 0 & 2 & 0 & 90 & 100 & 90 \\
\hline 10 & 20 & 0 & 0 & 0 & 100 & 100 & 100 \\
\hline 11 & 16 & 4 & 1 & 0 & 76,19 & 80 & 94,12 \\
\hline 12 & 17 & 1 & 2 & 0 & 85 & 94,44 & 89,47 \\
\hline 13 & 18 & 0 & 2 & 0 & 90 & 100 & 90 \\
\hline 14 & 20 & 0 & 0 & 0 & 100 & 100 & 100 \\
\hline 15 & 20 & 0 & 0 & 0 & 100 & 100 & 100 \\
\hline \multicolumn{5}{|c|}{ Rata-Rata } & 89,75 & 98,30 & 91,24 \\
\hline
\end{tabular}

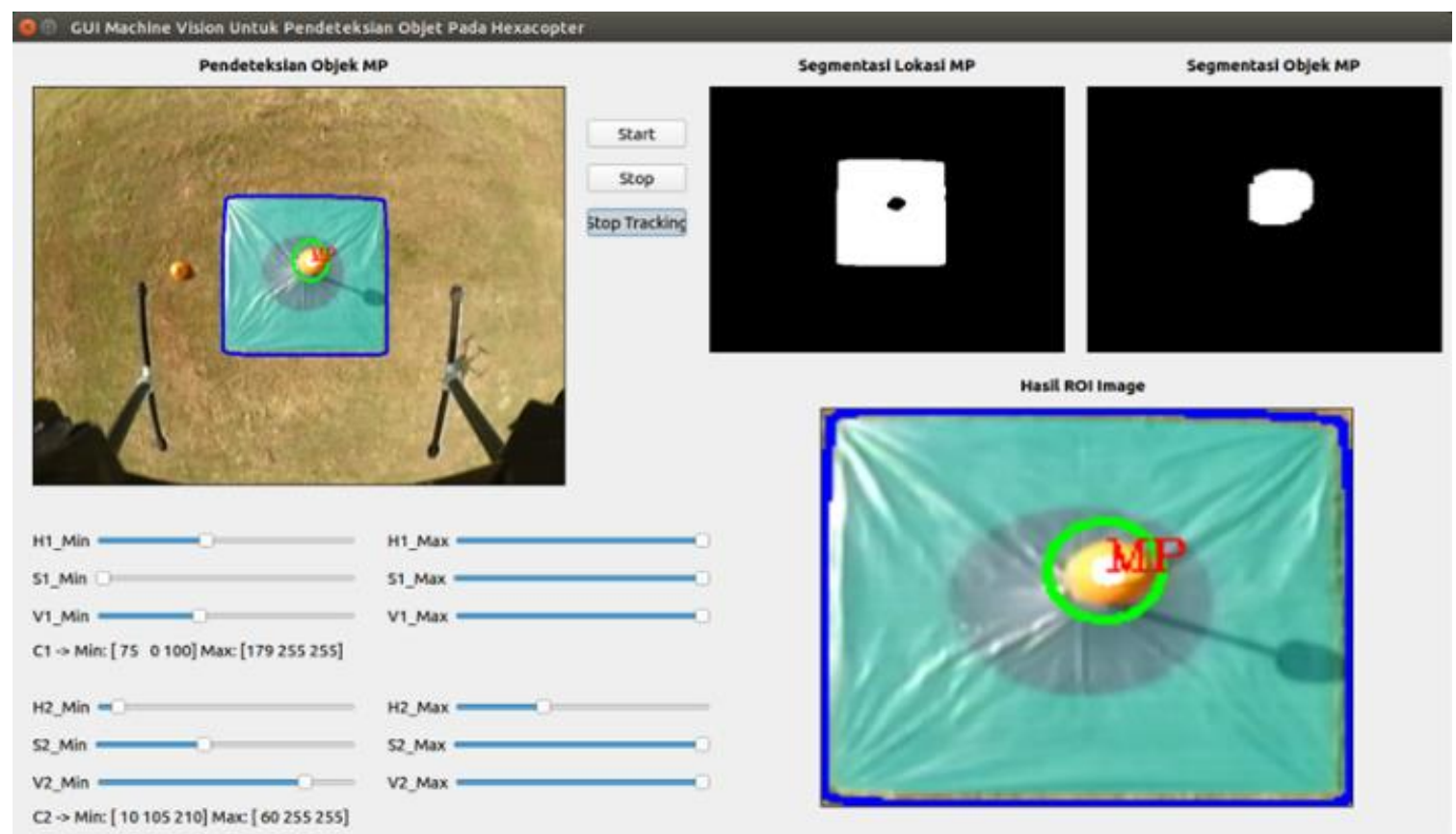

Gambar 4. Deteksi objek survival kits dengan gangguan objek dimensi sama 


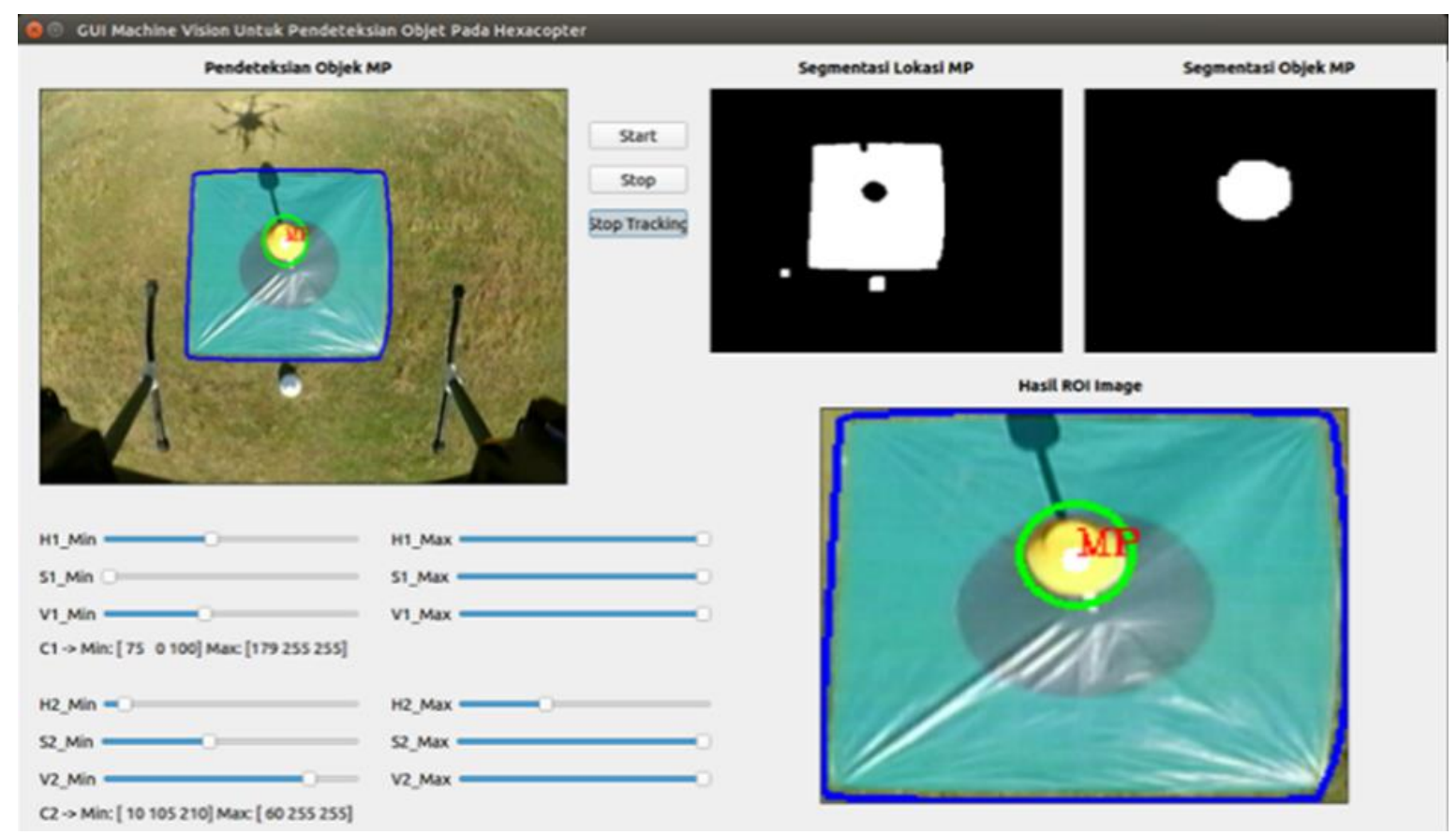

Gambar 5. Deteksi objek survival kits dengan gangguan objek warna lain

TABEL III. Hasil EVAluasi Segmentasi DENGan GangGuan OBJeK WARNA LAIN

\begin{tabular}{|c|c|c|c|c|c|c|c|}
\hline Uji & $\mathbf{T P}$ & FP & FN & $\mathbf{T N}$ & $\begin{array}{c}\text { Accuracy } \\
(\%)\end{array}$ & $\begin{array}{c}\text { Precision } \\
(\%)\end{array}$ & $\begin{array}{c}\text { Recall } \\
(\%)\end{array}$ \\
\hline 1 & 15 & 0 & 5 & 0 & 75 & 100 & 75 \\
\hline 2 & 17 & 0 & 3 & 0 & 85 & 100 & 85 \\
\hline 3 & 13 & 0 & 7 & 0 & 65 & 100 & 65 \\
\hline 4 & 19 & 0 & 1 & 0 & 95 & 100 & 95 \\
\hline 5 & 19 & 0 & 1 & 0 & 95 & 100 & 95 \\
\hline 6 & 20 & 0 & 0 & 0 & 100 & 100 & 100 \\
\hline 7 & 18 & 0 & 2 & 0 & 90 & 100 & 90 \\
\hline 8 & 20 & 0 & 0 & 0 & 100 & 100 & 100 \\
\hline 9 & 20 & 0 & 0 & 0 & 100 & 100 & 100 \\
\hline 10 & 17 & 0 & 3 & 0 & 85 & 100 & 85 \\
\hline 11 & 19 & 0 & 1 & 0 & 95 & 100 & 95 \\
\hline 12 & 20 & 0 & 0 & 0 & 100 & 100 & 100 \\
\hline 13 & 17 & 1 & 2 & 0 & 85 & 94,44 & 89,47 \\
\hline 14 & 18 & 0 & 2 & 0 & 90 & 100 & 90 \\
\hline 15 & 19 & 0 & 1 & 0 & 95 & 100 & 95 \\
\hline \multicolumn{5}{|c|}{ Rata-Rata } & 90,33 & 99,63 & 90,63 \\
\hline
\end{tabular}

C. Evaluasi Segmentasi Objek Survival Kits dengan Gangguan Objek Bentuk Lain

Evaluasi segmentasi objek survival kits dilakukan dengan diberikan gangguan objek berbentuk kubus berwarna oranye ukuran $20 \times 20 \times 10 \mathrm{~cm}^{3}$. Aplikasi GUI menampilkan nilai parameter warna HSV, hasil segmentasi lokasi MP survival kits, hasil segmentasi objek MP survival kits, hasil ROI image, dan hasil pengenalan objek MP survival kits ditunjukkan pada Gambar 6.

Pengambilan data menggunakan hexacopter yang diterbangkan ke lokasi survival kits dengan ketinggian $3 \mathrm{~m}$. Pengambilan data yang dilakukan dengan mengambil data sebanyak 20 frame citra dari video real-time berdurasi 1 menit pada setiap uji evaluasi. Evaluasi segmentasi objek survival kits dengan gangguan objek bentuk lain dilakukan sebanyak 15 kali uji. Hasil evaluasi segmentasi dengan gangguan objek bentuk lain ditunjukkan pada Tabel IV.

Mengacu pada Tabel IV, evaluasi segmentasi objek survival kits dengan gangguan objek bentuk lain diperoleh rata-rata hasil akurasi sebes ar $87,67 \%$, presisi sebesar $96,71 \%$, dan sebesar recall 90,39\%. Sistem yang dikembangkan pada UAV dapat mengenali dan tracking objek MP survival kits yang berada dalam area lokasi survival kits serta mampu mengabaikan gangguan objek bentuk lain di sekitar lokasi survival kits. Sistem mampu mengklasifikasikan hasil segmentasi sebagai objek survival kits walaupun diberikan gangguan objek bentuk lain sehingga diperoleh hasil akurasi yang tinggi sebesar $87,67 \%$. Akurasi rendah didapatkan pada evaluasi segmentasi uji ke-13. Dalam evaluasi segmentasi uji ke-13 menunjukkan sistem belum mampu melakukan segmentasi dengan baik diakibatkan kesalahan sistem yang tidak dapat mendeteksi objek survival kits. Faktor lain yang menyebabkan kesalahan deteksi objek survival kits diantaranya kamera tidak dapat menangkap objek survival kits dengan baik akibat gangguan komunikasi perangkat FPV pada saat pengiriman video real-time. 


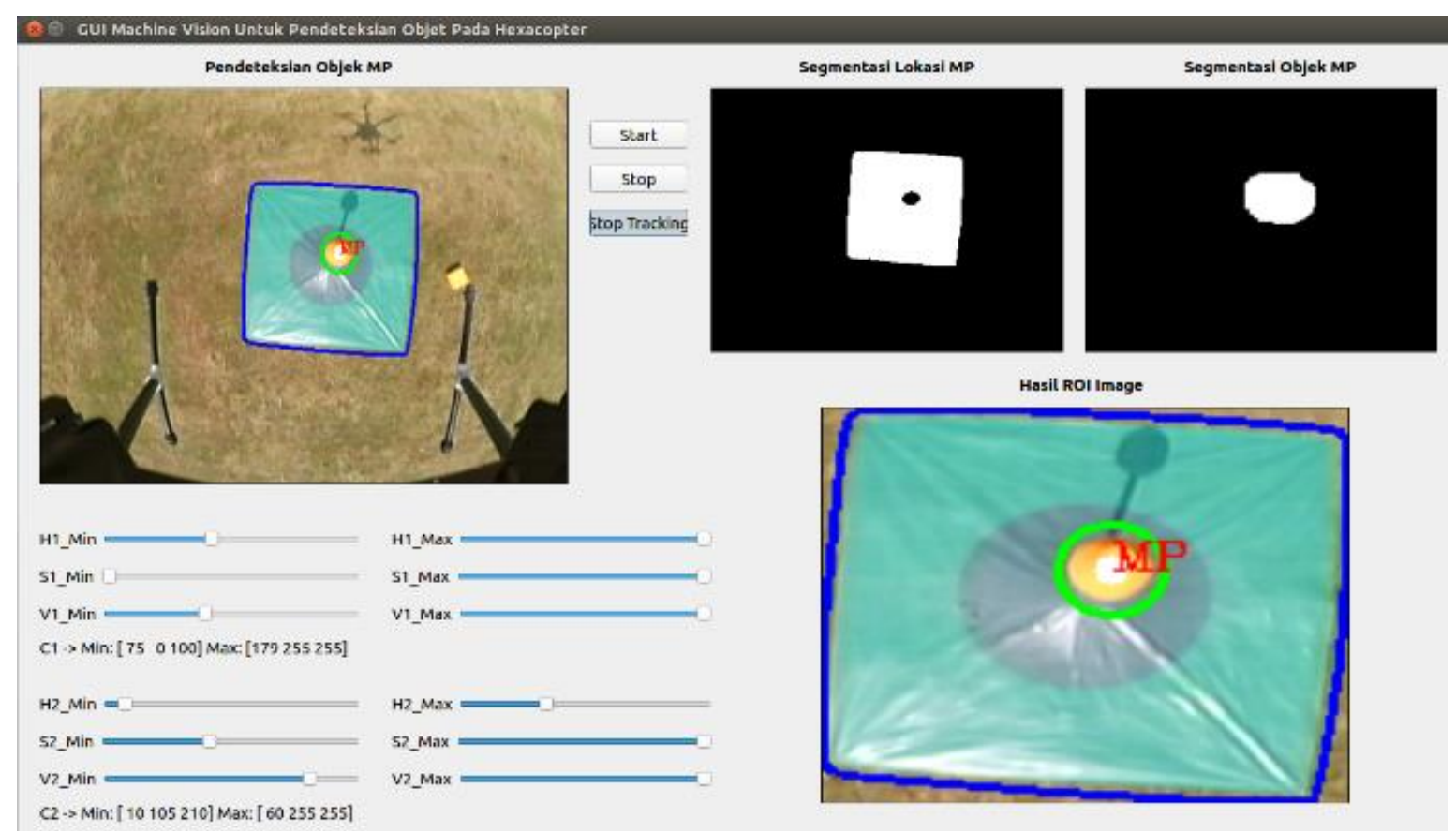

Gambar 6. Deteksi objek survival kits dengan gangguan objek bentuk lain

TABEL IV. Hasil EVAluasi Segmentasi DENGAN GangGuan OBJeK BENTUK LAIN

\begin{tabular}{|c|c|c|c|c|c|c|c|}
\hline Uji & TP & FP & FN & TN & $\begin{array}{c}\text { Accuracy } \\
(\%)\end{array}$ & $\begin{array}{c}\text { Precision } \\
(\%)\end{array}$ & $\begin{array}{c}\text { Recall } \\
(\%)\end{array}$ \\
\hline 1 & 17 & 0 & 3 & 0 & 85 & 100 & 85 \\
\hline 2 & 17 & 0 & 3 & 0 & 85 & 100 & 85 \\
\hline 3 & 20 & 0 & 0 & 0 & 100 & 100 & 100 \\
\hline 4 & 17 & 3 & 0 & 0 & 85 & 85 & 100 \\
\hline 5 & 20 & 0 & 0 & 0 & 100 & 100 & 100 \\
\hline 6 & 15 & 2 & 3 & 0 & 75 & 88,24 & 83,33 \\
\hline 7 & 18 & 0 & 2 & 0 & 90 & 100 & 90 \\
\hline 8 & 19 & 0 & 1 & 0 & 95 & 100 & 95 \\
\hline 9 & 15 & 3 & 2 & 0 & 75 & 83,33 & 88,24 \\
\hline 10 & 19 & 0 & 1 & 0 & 95 & 100 & 95 \\
\hline 11 & 19 & 0 & 1 & 0 & 95 & 100 & 95 \\
\hline 12 & 17 & 0 & 3 & 0 & 85 & 100 & 85 \\
\hline 13 & 14 & 0 & 6 & 0 & 70 & 100 & 70 \\
\hline 14 & 16 & 1 & 3 & 0 & 80 & 94,12 & 84,21 \\
\hline 15 & 20 & 0 & 0 & 0 & 100 & 100 & 100 \\
\hline \multicolumn{5}{|c|}{$\frac{1}{\text { Rata-Rata }}$} & 87,67 & 96,71 & 90,39 \\
\hline
\end{tabular}

Mengacu grafik pada Gambar 7, telah dilakukan 3 skema evaluasi segmentasi objek survival kits dilakukan dengan diberikan gangguan objek lain didapatkan hasil optimal. Hasil yang diperoleh adalah akurasi sebesar $90,33 \%$ pada evaluasi gangguan objek warna lain, presisi sebesar 99,63\% pada evaluasi gangguan objek warna lain, dan didapatkan recall sebesar 91,24\% pada evaluasi gangguan objek dimensi sama. Berdasarkan evaluasi segmentasi yang dilakukan yang telah dilakukan, hasil deteksi objek survival kits memiliki keberhasilan deteksi dan ketahanan terhadap gangguan objek lain melalui metode yang dikembangkan sehingga sistem mampu mendeteksi objek MP survival kits dengan baik dan mengabaikan gangguan objek lain di sekitarnya.

Penelitian ini telah melakukan pengembangan sistem machine vision pada UAV untuk pengenalan objek survival kits berdasarkan penelitian [8] yang belum menggunakan vision pada misi UAV untuk pengiriman survival kits. Pengenalan objek pada UAV dengan metode segmentasi warna RGB dan deteksi bentuk memiliki kelemahan terhadap perubahan intensitas cahaya dan gangguan objek lain sejenis [24]. Penggunaan machine vision metode segmentasi warna HSV memiliki keunggulan terhadap intensitas cahaya sehingga cocok digunakan dalam deteksi objek [17], [25]. Penerapan metode segmentasi objek pada ruang warna HSV, deteksi kontur, dan deteksi ROI yang telah dilakukan pada penelitian ini dapat meningkatkan hasil akurasi deteksi objek pada UAV dibandingkan pada penelitian [8] dan [24].

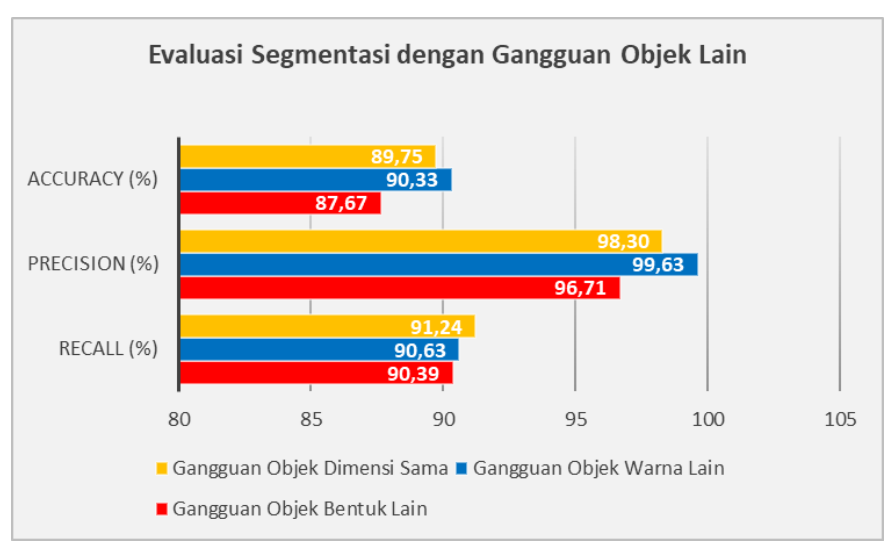

Gambar 7. Grafik hasil evaluasi dengan gangguan objek lain 


\section{PENUTUP}

Penelitian ini berfokus pada pengembangan sistem machine vision pada hexacopter untuk pendeteksian objek MP survival kits. Sistem machine vision pada hexacopter yang dikembangkan mampu mendeteksi objek MP survival kits dan mengabaikan objek gangguan di sekitar lokasi survival kits berdasarkan ciri warna dan bentuk. Deteksi ROI pada evaluasi segmentasi objek MP survival kits dengan gangguan objek lain sangat berpengaruh terhadap hasil deteksi objek survival kits. Hasil capaian keberhasilan deteksi objek survival kits yang telah diperoleh yaitu akurasi sebesar 90,33\%, presisi sebesar 99,63\%, dan recall sebesar 91,24\%. Penelitian lebih lanjut diharapkan dapat meningkatkan hasil akurasi pendeteksian objek survival kits dengan menambah data citra dan menggunakan metode klasifikasi objek lainnya, diantaranya ekstraksi fitur. Berdasarkan kinerja yang diperoleh dalam penelitian in $\mathrm{i}$, pengembangan sistem machine vision pada UAV memiliki ketepatan tinggi untuk deteksi objek survival kits meskipun diberikan gangguan objek lain. Keberhasilan pengenalan objek survival kits diharapkan dapat mendukung misi pengambilan dan dropping survival kits pada UAV.

\section{REFERENSI}

[1] D. Jo and Y. J. Kwon, "VerticalT akeoff and Landing Wing Developed for Long Distance Flight and Stable Transit Flight," Int. J. Mech. Eng. Robot. Res., vol. 8, no.5, pp. 797-802, 2019.

[2] S. Yu, J. Heo, S. Jeong, and Y. Kwon, "Technical Analysis of VTOL UAV," J. Comput. Commun., vol. 4, no. 15, pp. 92-97, 2016.

[3] V. Raja, Mano, Dinesh, S. Kumar, and R. Kumar, "Design, Fabrication and Simulation of Hexacopter For Forest Surveillance," ARPN J. Eng. Appl. Sci., vol. 12, no. 12, pp. 3879-3884, 2017.

[4] E. Setyaningsih, D. Prastiyanto, and Suryono, "Penggunaan Sensor Photodioda sebagai Sistem Deteksi Api pada Wahana Terbang Vertical Take-Off Landing (VTOL)," J. Tek. Elektro, vol. 9, no. 2, pp. 53-59, 2017.

[5] G. Patankar, S. Ramdasi, K. Shukla, and P. Yadav, "Autonomous Operation and Controlling of Unmanned Ariel Vehicle (UAV) using Internet," Int. Res. J. Eng. Technol., vol. 6, no. 3, pp. 427-230, 2019.

[6] A. Tiwari and A. Dixit, "Unmanned Aerial Vehicle and Geospatial Technology Pushing the Limits of Development," Am. J. Eng. Res., vol. 4, no. 1, pp. 16-21, 2015.

[7] D. Jo and Y. Kwon, "Development of Rescue Material Transport UAV (Unmanned Aerial Vehicle)," World J. Eng. Technol., vol. 5, no. 4, pp. 720-729, 2017.

[8] M. Junus, J. A. Prasetyo, and R. H. Y. Perdana, "Vertical Take Off Landing (VTOL) Untuk Drop Kits Pada Quadcopter," J. Appl. Smart Electr. Netw. Syst., vol. 1, no. 1, pp. 25-30, 2020.

[9] E. M. Pamungkas, B. A. A. Sumbodo, and I. Candradewi, "Sistem Pendeteksi dan Pelacakan Bola dengan Metode Hough Circle
Transform, Blob Detection, dan Camshift Menggunakan AR.Drone," IJEIS, vol. 7, no. 1, pp. 1-12,2017.

[10] R. M. Faheem, S. Aziz, A. Khalid, and M. Bashir, "UAV Emergency Landing Site Selection System using Machine vision," J. Mach. Intell., vol. 1, no. 1, pp. 13-20, 2015.

[11] D. J. Bora, A. K. Gupta, and F. A. Khan, "Comparing the Performance of $\mathrm{L}^{*} \mathrm{~A} * \mathrm{~B}$ and HSV Color Spaces with Respect to Color Image Segmentation," Int. J. Emerg. Technol. Adv. Eng., vol. 5, no. 2, pp. 192-203, 2015.

[12] K. A. Eldahshan, M. I. Youssef, E. H. Masameer, and M. A. Mustafa, "Comparison of Segmentation Framework on Digital Microscope Images for Acute Lymphoblastic Leukemia Diagnosis using RGB and HSV Color Spaces," J. Biomed. Eng. Med. Imaging, vol. 2, no. 2, pp. $26-34,2015$.

[13] A. Pradipta and Desiana Wulaning Ayu, "Perbandingan Segmentasi Citra Telur Ayam Menggunakan Metode Otsu Berdasarkan Perbedaan Ruang Warna RGB Dan HSV," J. Sains dan Teknol., vol. 6, no. 1, pp. 136-147, 2017

[14] M. N. A. Hussin, A. H. Ahmad, and M. A. A. Razak, "Price Tag Recognition using HSV Color Space," J. Telecommun. Electron. Comput.Eng., vol. 9, no. 3, pp. 77-84, 2017.

[15] B. Hdioud, M. E. H. Tirari, R. O. H. Thami, and R. Faizi, "Detecting and Shadows in the HSV Color Space using Dynamic Thresholds," Int. J. Electr. Comput. Eng., vol. 8, no. 3,pp. 1513-1521, 2018.

[16] C. M. Ibraheem and G. U. Reddy, "Content Based Image Retrieval using HSV Color, Shape and GLCM Texture," Int. J. Adv. Res. Comput. Commun. Eng., vol. 4, no. 10,pp.378-383, 2015.

[17] N. S. Widodo and A. Pamungkas, "Machine vision-based Obstacle Avoidance for Mobile Robot," J. Ilm. Tek. Elektro Komput. dan Inform., vol. 5, no. 2, pp. 77-84, 2019.

[18] E. Hamuda, B. M. Ginley, M. Glavin, and E. Jones, "Automatic Crop Detection Under Field Conditions using the HSV Colour Space and Morphological Operations," Comput. Electron. Agric., vol. 133, pp. 97-107, 2017.

[19] A. H. Pratomo, W. Kaswidjanti, and S. Mu'arifah, "Implementasi Algoritma Region of Interest (ROI) Untuk Meningkatkan Performa Algoritma Deteksi Dan Klasifikasi Kendaraan," J. Teknol. Inf. dan Ilmu Komput., vol. 7, no. 1, pp. 155-162,2020.

[20] C.-Y. Huang, J.-H. Hong, and E. Huang, "Developing a Machine vision Inspection System for Electronics Failure Analysis," IEEE Trans. Components, Packag. Manuf. Technol., vol. 9, no. 9,pp. 1-32, 2019.

[21] J. P and Geethu Balakrishnan, "Contour Based Object Tracking," Int. J. Comput. Sci. Inf. Technol., vol. 5, no. 3, pp. 4128-4130, 2014.

[22] A. Hatekar, S. Manwani, G. Patil, and A. Parekh, "Fire Detection on a Surveillance System using Image Processing," Int. J. Eng. Res. Technol., vol. 6, no. 5, pp. 121-125, 2017.

[23] A. A. Babu, S. Varma, and R. Nikhare, "Hand Gesture Recognition System for Human Computer Interaction using Contour Analysis," Int. J. Res. Eng. Technol., vol. 4, no. 3,pp. 11-19, 2015.

[24] D. B. Jatmiko, G. E. Setyawan, and H. Fitriyah, "Sistem Tracking Objek Menggunakan Metode Edge Detection pada Quadcopter," J. Pengemb. Teknol. Inf. dan Ilmu Komput., vol. 3, no. 8, pp. 8031-8036, 2019.

[25] S. Panwar and B. Kaushal, "Determination of Accuracy of Intensity Based Segmentation in HSV Color Space," Int. J. Adv. Res. Electron. Commun.Eng., vol. 4, no. 6, pp. 1568-1571, 2015. 